Original Research Paper

\title{
Effects of Temperature and pH on the Growth of Sargassum linearifolium and $S$. podacanthum in Potassium-Fortified Inland Saline Water
}

\author{
Ha Thi Thu Bui, Trong Quoc Luu and Ravi Fotedar \\ School of Molecular and Life Sciences, \\ Curtin University, Kent Street, Bentley, Perth, Western Australia, 6102, Australia
}

\author{
Article history \\ Received: 08-12-2018 \\ Revised: 02-02-2018 \\ Accepted: 05-04-2018 \\ Corresponding Author: \\ Ha Thi Thu Bui \\ School of Molecular and Life \\ Sciences, Curtin University, \\ Kent Street, Perth, Western, \\ Australia, 6102, Australia \\ Email: habtt76@gmail.com
}

\begin{abstract}
This study tested the effects of temperature and $\mathrm{pH}$ on water quality and the growth of Sargassum linearifolium and S. podacanthum in potassium-fortified Inland Saline Water (ISW) of Western Australia (WA), at two levels of $\mathrm{pH}$ (low $\mathrm{pH}$ range of 5.5-6.5 and ambient $\mathrm{pH} 7.0-8.2$ ) and two levels of temperature (high temperature $26-27^{\circ} \mathrm{C}$ and ambient room temperature of $20-22^{\circ} \mathrm{C}$ ) in triplicate for 42 days. The $\mathrm{pH}$ of ISW in WA varies from 3.9 to 9.1 , whereas the temperature is from $6.1-28.1{ }^{\circ} \mathrm{C}$. The results showed that the high temperature initiated the mortalities of the both Sargassum species from the first 14 days of culture period. The high temperature also resulted in a reduction of dried weight and ash content of these two species of Sargassum by the end of the trial. S. linearifolium temperature tolerant threshold was larger than $S$. podacanthum. Since the day 14 , the $S$. linearifolium biomass and specific growth rate were higher than $S$. podacanthum at both temperature levels under ambient $\mathrm{pH}$. Higher crude protein in S. linearifolium than S. podacanthum was also recorded at high temperature. Ambient $\mathrm{pH}$ and ambient temperature resulted in higher biomass and higher specific growth rate than low $\mathrm{pH}$ and high temperature in both species, which is recommended for Sargassum spp. growth.
\end{abstract}

Keywords: pH, Temperature, Sargassum linearifolium, Sargassum podacanthum, Biomass

\section{Introduction}

Australia has a significant Inland Saline Water (ISW) resource (Nulsen, 1997; Allan et al., 2001; Timms, 2005). The wheat-belt area in Western Australia (WA), covering approximately 18 million hectares is the largest underground source of ISW in Australia (Doupé et al., 2003; Lymbery et al., 2006) that could provide a source of water for inland marine aquaculture (Partridge, 2008). Targeting to the farm sustainability and environmental protection, the land management of nearly 30,000 farms in Australia has changed to prevent the expansion of salinization, 470,000 hectares of land were fenced and $210,000 \mathrm{~km}$ of levees, banks, drains for salinity management has been built (ABS, 2002), providing an available water source for ISW aquaculture. Building onshore farm to culture seaweeds is cheaper than seaweed farms in the open sea (Borowitzka, 1997), as well as contributing to environmental protection by reducing the salinity contamination (Ogburn, 1997), considering the availability of inland water resources and farm infrastructure.
Sargassum has been cultivated in many countries, such as Korea, Japan and India, for human consumption (Bast, 2014) includes S. naozhouense and S. fusiforme (Wang et al., 2010a; Bast, 2014). The Sargassum have been used commonly in Asia as a source of alginate and medicine for human (Yende et al., 2014; Wiltshire et al., 2015). For instance, S. naozhouense has been used as a source of food and drugs for traditional orientation treatments (Hur et al., 2008; Wang et al., 2010b). Sargassum also provides a source of sargaquinoic acid, sargachromenol for neurite growth and survival (Hur et al., 2008). The Sargassum can also be used for agriculture as biochemical compounds, cattle food, fertilizer (Ara et al., 1997; Huisman, 2000).

Both S. linearifolium and S. podacanthum can be found in Western Australia including around Perth beaches (Womersley, 1987). In South Australia, only rope-culture trial of $S$. linearifolium in the ocean has been practiced with low specific growth rate (Wiltshire et al., 2015), specially under summer conditions, when the temperature is from $28-32^{\circ} \mathrm{C}$ 
(Martin-Smith, 1993; Wiltshire et al., 2015). However, little is known about the culture potential and the environmental requirements for these two species, particularly the environment around ISW conditions has not been investigated. Both species of Sargassum could be ideal species for culture as plenty of available ISW during the winter months, meet the growing-seasonal requirements under $28^{\circ} \mathrm{C}$ of the $S$. linearifolium (MartinSmith, 1993).

At the same salinity, the ISW ionic profile in Australia can be similar to the Ocean Water (OW) (Fielder et al., 2001; Prangnell and Fotedar, 2006a), but the potassium concentration $\left(\left[\mathrm{K}^{+}\right]\right)$is much lower (Ingram et al., 2002; Boyd et al., 2007) and varies (Nurmi et al., 1988; Nulsen, 1997). It is not feasible for marine shrimp, fish and mollucs to survive and grow without $\mathrm{K}^{+}$fortification, similar to $\mathrm{K}^{+}$levels to $\mathrm{OW}$ (Fielder and Allan, 2003; Doroudi et al., 2006; Prangnell and Fotedar, 2006b; Dinh, 2016). The S. linearifolium also needs $\mathrm{K}^{+}$-fortified at similar $\mathrm{K}^{+}$concentration in OW to sustain its growth in ISW (Bui et al., 2017b). In southwest WA, while the pH of OW is stable from 7.88.2, salinity from 35.5-36.5 (Hoang et al., 2016) and temperature of $22.0-32.0^{\circ} \mathrm{C}$ (Martin-Smith, 1993), the $\mathrm{pH}$, salinity and temperature of ISW in the wheat belt of WA are generally varied by the depth and location of the groundwater (Nurmi et al., 1988; Nulsen, 1997; Taukulis and John, 2009). The $\mathrm{pH}$ varies from 3.9 to 9.7 in the wheat belt of WA (Nulsen, 1997; Taukulis and John, 2006), or 7.4 at 35 ppt in Broome (Lee, 1997; Taukulis and John, 2006). The pH of ISW is lower and unstable than OW (Lee, 1997). The salinity of inland water in WA varies from 0 to $320 \mathrm{ppt}$ and two-thirds of those areas has salinity 5-40 ppt (Mazor and George, 1992), which is suitable for the growth of seaweed, including Sargassum (Hwang et al., 2006; Jie et al., 2008). The temperature of ISW in WA is from $6.3-28.1^{\circ} \mathrm{C}$ with an average of $17.7^{\circ} \mathrm{C}$ (Taukulis and John, 2009). The pH and temperature are the two environmental factors that strongly influence the growth and heavy metal biosorption of Sargassum spp. (Davis et al., 2000). In OW, the chlorophyll fluorescence of $S$. fusiforme and $S$. fulvellum varies little over in the $\mathrm{pH}$ of 4-10 (Hwang et al., 2015) and the suitable $\mathrm{pH}$ for $S$. honeri zygote germination is 5-10 (Ogawa, 1984). Similarly, the temperature is a vital factor affecting Sargassum growth (Uchida, 1993). The optimal growth temperature for $S$. muticum is at $25^{\circ} \mathrm{C}$ (Hales and Fletcher, 1989), while S. patents prefers $20-30^{\circ} \mathrm{C}$ (Endo et al., 2013).

ISW in WA is characterized by high changes in $\mathrm{pH}$ and temperature by location and seasons. In a contribution to the use of ISW for aquaculture to reduce the adverse impact of salinization (Kolkovski, 2010), an attempt to grow the Sargassum in $\mathrm{K}^{+}$fortified ISW ( $\mathrm{K}^{+} \mathrm{ISW}$ ) has been investigated by investigating what temperature and $\mathrm{pH}$ are conducive to grow these two Sargassum species in ISW. Therefore, this study aims to evaluate the effects of temperature and $\mathrm{pH}$ on the growth of $S$. linearifolium and $S$. podacanthum and water quality in $\mathrm{K}^{+} \mathrm{ISW}$.

\section{Materials and Methods}

\section{Preparation of Sargassum Species}

Sargassum linearifolium and S. podacanthum were hand-picked from Point Peron, WA (latitude $32^{\circ} 16.3^{\prime}$ 'S, longitude $115^{\circ} 41.2^{\prime} \mathrm{E}$ ) and then transported for two hours in containers filled with OW to Curtin Aquatic Research Laboratory (CARL). At CARL, the species were rinsed with OW to remove all surface fouling, sediments and epiphytic algae. Next, the Sargassum were acclimated for three days in aerated OW under indoor laboratory conditions (ambient room temperature, the light provided by plant white fluorescent lights of $90 \mu \mathrm{mol}$ photon $\mathrm{m}^{-2} \mathrm{~s}^{-1}$ on a 14:10 h light:dark cycle, one third of OW was exchanged everyday) and then treated according to the procedures of Schaffelke and Klumpp (1998) to clean the thalli followed by (1) discarding all visible macroepiphytes, (2) wiping with soft tissue, (3) washing in filtered OW and then quickly washed in fresh water, (4) and puting into filtered OW for one day to recover.

The whole Sargassum thallus including holdfasts was chosen at the pre-selected weight of about $145 \mathrm{~g} \mathrm{fond}^{-1}$, dried by paper towel, weighed (Model GX-4000, A\&D Company Limited, Tokyo, Japan) and then placed into tanks to get stocking densities of and then placed into tanks to get stocking densities of $0.8 \mathrm{~kg} \mathrm{~m}^{-2}$. The Sargassum thalli with similar height and weight were selected and their holdfasts were attached to gravel particles to keep them submerged in water.

\section{Preparation of Inland Saline Water}

The ISW at a salinity of $45 \mathrm{ppt}$ was procured from a lake in Wannamal, WA $\left(31^{\circ} 15 \mathrm{~S}, 116^{\circ} 05 \mathrm{E}\right)$ and transported to CARL. The ISW was stored and aged in a reservoir of 10,000L for the duration of the experiment. The ISW was filtered through a $0.5 \mu \mathrm{m}$ glass fibre membrane, then diluted with filtered fresh water to get the $35 \mathrm{ppt}$ water used in this experiment. The $\left[\mathrm{K}^{+}\right]$in ISW was fortified to a level of $100 \%$ of the $\left[\mathrm{K}^{+}\right]$in OW by adding potash of sulphate $\mathrm{K}_{2} \mathrm{SO}_{4}$ receive cultured media $\mathrm{K}^{+} \mathrm{ISW}$. As the $\left[\mathrm{K}^{+}\right.$in OW and ISW at $35 \mathrm{ppt}$ is 351.1 and $84.4 \mathrm{mg} \mathrm{L}^{-1}$ respectively; therefore, $642 \mathrm{mg}$ $\mathrm{L}^{-1} \mathrm{~K}_{2} \mathrm{SO}_{4}$ was added into ISW to achieve the desired $\left[\mathrm{K}^{+}\right]$of ISW. The $\mathrm{HNO}_{3}$ was then added to water to reduce the $\mathrm{pH}$ to $5.5-6.5$ and maintained at this $\mathrm{pH}$ level during the whole trial by adding $\mathrm{HNO}_{3}$ daily at noon. During the experiment, the salinity of $\mathrm{K}^{+} \mathrm{ISW}$ was maintained within a range of 34-35 ppt in all the experimental tanks by adding fresh water to compensate for any increases in salinity due to evaporation. 
Table 1: Eight treatments of the experiment testing the effect of two $\mathrm{pH}$ and two temperature levels on the growth of Sargassum linearifolium and S. podacanthum in $\mathrm{K}^{+}$-fortified inland saline water

\begin{tabular}{llll}
\hline Treatment & Species & $\mathrm{pH}(*)$ & Temperature $(* *)$ \\
\hline T1 & S. linearifolium & $7.94 \pm 0.01$ & $21.67 \pm 0.08$ \\
T2 & S. linearifolium & $6.12 \pm 0.06$ & $21.54 \pm 0.08$ \\
T3 & S. linearifolium & $7.93 \pm 0.00$ & $26.67 \pm 0.09$ \\
T4 & S. linearifolium & $6.30 \pm 0.03$ & $26.73 \pm 0.06$ \\
T1 & S. podacanthum & $7.91 \pm 0.02$ & $21.73 \pm 0.08$ \\
T2 & S. podacanthum & $6.04 \pm 0.08$ & $21.68 \pm 0.12$ \\
T3 & S. podacanthum & $7.91 \pm 0.04$ & $26.71 \pm 0.11$ \\
T4 & S. podacanthum & $6.02 \pm 0.20$ & $26.73 \pm 0.04$ \\
\hline
\end{tabular}

$(*)$ - No significant difference of the $\mathrm{pH}$ at the same levels (Ambient $\mathrm{pH}$ : T1 and T3; Lower $\mathrm{pH}$ : T2 and T4) (t-test, $\mathrm{p}>0.05, \mathrm{~N}=3$ ); $(* *)$ - No significant difference of the temperature at the same levels (Ambient temperature: T1 and T2; higher temperature: T3 and T4) (t-test, $\mathrm{p}>0.05, \mathrm{~N}=3$ )

\section{Experimental Setup}

The experiment was conducted for 42 days using a total of 24 glass tanks of $54 \mathrm{~L}(60 \times 30 \times 30 \mathrm{~cm})$, each holding $45 \mathrm{~L}$ of $\mathrm{K}^{+} \mathrm{ISW}$. The treatments included two levels of $\mathrm{pH}$ (ambient of about 8 and lower at 5.5-6.5, of which the lower level is the natural acidity of ISW in many places (Partridge et al., 2008), two water temperatures (ambient room temperature $21-22^{\circ} \mathrm{C}$ and higher at $26-27^{\circ} \mathrm{C}$, which is the upper temperature level of ISW in WA (Taukulis and John, 2006) and two species of Sargassum ( $S$. linearifolium and $S$. podacanthum) (Table 1). These eight treatments were randomly triplicated. The tanks were aerated by two air stones in two sides of each tank and exposed to a plant white fluorescent lights of $90 \mu \mathrm{mol}$ photon $\mathrm{m}^{-2} \mathrm{~s}^{-1}$ on a 14:10 h light:dark cycle (Hanisak and Samuel, 1987). One submersible automatic heater (Sonpar. Model: HA200, Zhongshan, Guangdong, China) was used for a tank to maintain a higher temperature of $26-27^{\circ} \mathrm{C}$.

\section{Data Collection}

Nitrogen $\left(\mathrm{NO}_{3}^{-}-\mathrm{N}, \mathrm{NO}_{2}^{-}-\mathrm{N}, \mathrm{NH}_{4}-\mathrm{N}\right)$ and phosphorus $\left(\mathrm{PO}_{4}{ }^{3-} \mathrm{P}\right)$ were measured every 14 days, using a Hach DR890 hand-held meter (Hach, Loveland, Colorado, USA). The Cadmium Reduction Method (Method 8171 and Method 8039) was used to measure $\mathrm{NO}_{3}{ }^{-} \mathrm{N}$ at low $\left(0-5 \quad \mathrm{mg} \mathrm{L} \mathrm{L}^{-1}\right)$ and higher concentrations. The Diazotization Method (Method 8507) was used to measure $\mathrm{NO}_{2}^{-}-\mathrm{N}$ at a lower range $\left(0-0.350 \mathrm{mg} \mathrm{L}^{-1}\right)$ and the Ferrous Sulfate Method (method 8153) was used to measure $\mathrm{NO}_{2}^{-}-\mathrm{N}$ at a higher range $\left(0-150 \mathrm{mg} \mathrm{L}^{-1}\right)$. The Salicylate Method (Method 8155; Method 10023) was used for $\mathrm{NH}_{4}-\mathrm{N}$ at $0-0.05 \mathrm{mg} \mathrm{L} \mathrm{L}^{-1}$ and higher concentrations and $\mathrm{PO}_{4}{ }^{3-}-\mathrm{P}$ was measured by the Amino Acid Method (Method 8178). Method 937.48 from the Official Method of the AOAC (Helrich, 1990) to analyse $\mathrm{N}$ was applied to measure Total Kjeldahl Nitrogen (TKN) using a Kjeltec Auto 1030 analyzer (Foss Tecator, Hoganas, Sweden) every 14 days.

Salinity and Dissolved Oxygen (DO) were recorded daily from 9:00-11:00 using a portable refractometer
(RHS-10ATC, Xiamen Ming Xin Instrument, Xiamen, Fujian, China) and a DO meter (YSI model 58, Yellow Springs Instrument Co., Ohio, USA) respectively. The temperature was recorded hourly by data loggers (HOBO Pendant temperature/light Data Logger UA002-08, UA-002-64). The $\mathrm{pH}$ was recorded daily at 9:00-11:00 and 13:00-15:00 using a pH meter (CyberScan pH 300, Eutech Instrument, Singapore). Once a fortnight, the $\mathrm{pH}$ and $\mathrm{DO}$ variations in a day was collected hourly.

The ionic profile of cultured medium was analyzed using Inductively Coupled Plasma (ICP) spectroscopy at CSBP Soil and Plant Laboratory, Bibra Lake, WA.

The fresh biomass of Sargassum was measured every 14 days to calculate Specific Growth Rate (SGR) by collecting the whole thalli in each tank by a small net and then dried by paper towels. The thalli were weighed using a scale (AW220, $d=0.1 \mathrm{mg}$, Shimazu, Japan) and returned to their respective tanks.

The SGR of Sargassum was calculated as: $\mu_{a}=\left(\ln A_{t^{-}}\right.$ $\left.\ln A_{o}\right) \times 100 / t$. Where: $\mu_{a}$ was the SGR $\left(\% \mathrm{~d}^{-1}\right) ; A_{o}$ and $A_{t}$ were the initial and final dried weights $(\mathrm{mg})$ of the Sargassum in a fortnight; $t=14$ (days).

Samples of approximately $10 \%$ of the fresh Sargassum were weighed and dried at $60^{\circ} \mathrm{C}$ for $72 \mathrm{~h}$ to get stable dried weights. They were then ground with a mortar and pestle to a fine powder and stored in a freezer at $-18^{\circ} \mathrm{C}$ until the proximate composition was analyzed. The dried content of Sargassum was calculated by the ratio of the dried weight to fresh biomass. The ash content was determined by burning dried Sargassum at $550^{\circ} \mathrm{C}$ for $30 \mathrm{~min}$.

Tissue $\mathrm{N}$ was determined every 14 days according to the Official Method of the AOAC (Helrich, 1990) (method 937.48) by analyzing $\mathrm{N}$ using a Kjeltec Auto 1030 analyzer (Foss Tecator, Höganäs, Sweden). The percentage of protein over the dried weight was calculated by multiplying the percent of $\mathrm{N}$ with a factor of 6.25 .

At the commencement and day 28 of the experiment, the ionic composition of the Sargassum was analyzed using the prepared freeze fine powder by ICP spectroscopy at CSBP Soil and Plant Laboratory, Bibra 
Lake, WA. The total N and total C of Sargassum were also analyzed at the CSBP Soil and Plant Laboratory, Bibra Lake, WA.

\section{Data Analysis}

The SPSS for Windows version 24.0 was used to analyze data. Before applying parametric and nonparametric tests, the data were tested for normality and homoscedasticity. Multivariate Analysis of Variance (MANOVA), pair samples t-test and Least Significant Difference post hoc tests were used to determine the significant differences at $\mathrm{p}<0.05$ among the means of tested variables. Regresssion correlations were used to find out the significant relationships among variables. The one-way Analysis of Covariance (ANCOVA) was used to determine the significance difference between the treatments of the water quality parameters on the SGR of the seaweeds.

Percentage data were arcsine-transformed and the homogeneity of variances confirmed with Cochran's test. Where the numeral data did not have a normal distribution and homogeneous variance, the KruskalWallis (KW test) was used to verify the overall difference of all treatments and data were transformed by $\log (x+10)$ before conducting MANOVA test.

\section{Results}

\section{Biomass of the Sargassum Species}

At the commencement of the experiment, the fresh biomass (approximately $145 \mathrm{~g} \mathrm{tank}^{-1}$ ) of the Sargassum was similar among the eight treatments. The $\mathrm{pH}$ and temperature significantly $(\mathrm{p}<0.05)$ affected Sargassum biomass in the first 28 days and the $\mathrm{pH}$ and Sargassum species significantly $(\mathrm{p}<0.05)$ interacted at day 28 of the trial. At the ambient temperature, the lower $\mathrm{pH}$ resulted in significantly $(\mathrm{p}<0.05)$ higher standing biomass of both species than the ambient $\mathrm{pH}$ of 7-8. The fresh standing biomass of both species at ambient temperature was significantly greater than at higher temperature over the trial period. The higher temperature resulted in a reduction of $S$. podacanthum and $S$. linearifolium biomass from the first and second week, respectively, followed by the total mortality by day 42 . The $S$. podacanthum showed $100 \%$ motality in the ambient $\mathrm{pH}$ and higher temperatures during the day 14-28 of the experiment, whereas after the day 28 , the $S$. linearifolium survived longer than $S$. podacanthum at both $\mathrm{pH}$ levels. However, none of them could survive after 42 days under higher temperature levels. The fresh standing biomass of $S$. linearifolium was significantly $(\mathrm{p}<0.05)$ higher than the $S$. podacanthum as the experiment progressed under ambient $\mathrm{pH}$ and under ambient temperature. The standing biomass of both species was not affected by the higher temperature and lower $\mathrm{pH}$ during the second fortnight but was significantly different in the first 14 days.

There was no significant interaction in the three-way interaction among species, $\mathrm{pH}$ and temperature on Sargassum SGR $\mathrm{F}_{(2,24)}=0.43$ at the first 14 days $(p>0.05)$. Due to the total mortality in some tanks, the three-way ANOVA could not be performed after 28 days. The $\mathrm{pH}$ and temperature had significantly $(\mathrm{p}<0.05)$ interactive effects on the SGR of the Sargassum.

The SGR of the $S$. linearifolium was significantly $(\mathrm{p}<0.05)$ higher than the $S$. podacanthum in the first 14 days; however, due to the mortality at high temperature, the comparison between the two species could not be drawn. Only at the ambient temperature and ambient $\mathrm{pH}$ conditions, where the Sargassum spp. grew continuously, the $S$. linearifolium presented significantly $(\mathrm{p}<0.05)$ higher SGR than $S$. podacanthum over the experiment period. The SGRs of the two species were similar in other treatments as the experiment progressed (Table 2).

The effects of treatments on SGR of the Sargassum were only recorded at the first 14 days. By that time, the SGR of S. linearifolium was positive under the ambient temperature, which was significantly $(p<0.05)$ higher than under higher temperature. At ambient temperature, SGR of $S$. podacanthum in lower $\mathrm{pH}$ was significantly higher than in ambient $\mathrm{pH}$.

\section{Compositions of the Sargassum}

The dried weight of Sargassum was about $13 \%$ of the total fresh biomass at the commencement of the experiment and was similar in both species. The dried weight of $S$. linearifolium was significantly $(\mathrm{p}<0.05)$ reduced at both higher temperature and lower $\mathrm{pH}$. The dried weight of $S$. podacanthum remained unchanged in all treatments (Table 2).

The ash content of the $S$. linearifolium $(37.06 \pm 0.49 \%)$ was significantly $(\mathrm{p}<0.05)$ lower than $S$. podacanthum $(44.14 \pm 0.67 \%)$ at the commencement of the trial, but became similar during the rest of the experiment, except at ambient temperature and low $\mathrm{pH}$ in the second fortnight (Table 2). A significant $(\mathrm{p}<0.05)$ reduction in ash content over time occurred in all treatments, but to the greatest extent in lower $\mathrm{pH}$ and higher temperature. The energy of the Sargassum was approximate $10,356 \pm 29.25 \mathrm{~J} \mathrm{~g}^{-1}$ and remained unchanged over the experiment period.

The protein contents of $S$. linearifolium and $S$. podacanthum at the commencement of the trial were similar $(8.05 \pm 1.01$ and $7.74 \pm 0.48 \%$, respectively) and then significantly $(\mathrm{p}<0.05)$ increased as the experiment progressed. The ambient $\mathrm{pH}$ resulted in a higher $(\mathrm{p}<0.05)$ protein than the lower $\mathrm{pH}$ in $S$. podacanthum and high temperature resulted in higher $(\mathrm{p}<0.05)$ protein in $S$. linearifolium than $S$. podacanthum. 
Table 2: SGR, dried weight, ash and protein content of the Sargassum spp. cultured in $\mathrm{K}^{+}$-fortified inland saline water at two levels of $\mathrm{pH}$ and two levels of temperature

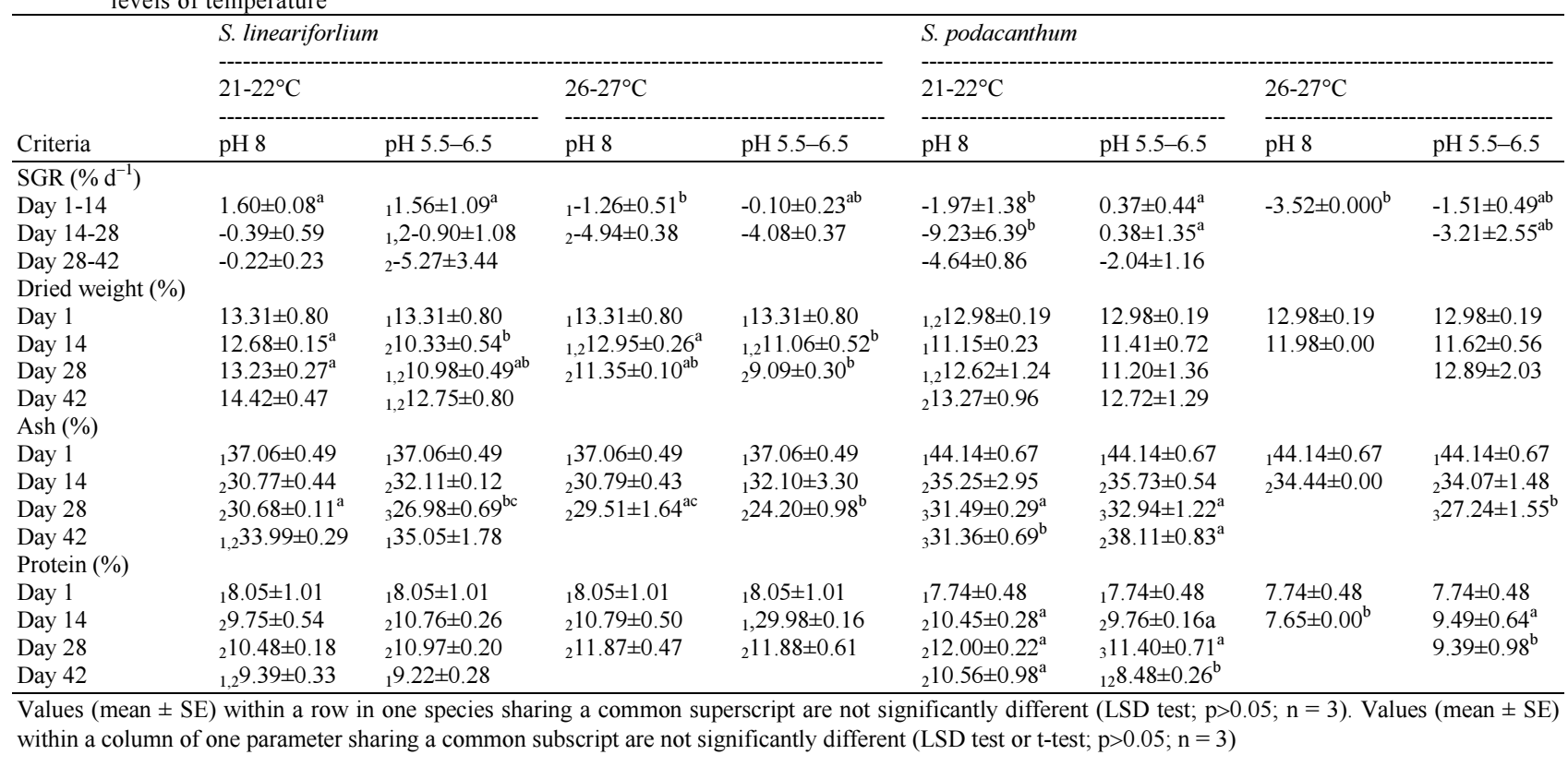

Table 3: The chemical compositions of the Sargassum spp. cultured in $\mathrm{K}^{+}$-fortified inland saline water at two levels of pH and two levels of temperature by day 1 and day 28 of the experiment

\begin{tabular}{|c|c|c|c|c|c|c|c|c|c|c|}
\hline \multirow[b]{4}{*}{ Parameters } & \multirow[b]{4}{*}{ Unit } & \multicolumn{5}{|c|}{ S. linearifolium } & \multicolumn{4}{|c|}{ S. podacanthum } \\
\hline & & \multirow[b]{3}{*}{ Day 1} & \multicolumn{4}{|l|}{ Day 28} & \multicolumn{4}{|c|}{ Day 28} \\
\hline & & & \multicolumn{2}{|l|}{$21-22^{\circ} \mathrm{C}$} & \multicolumn{2}{|l|}{$26-27^{\circ} \mathrm{C}$} & \multirow[b]{2}{*}{ Day 1} & \multicolumn{2}{|l|}{$21-22^{\circ} \mathrm{C}$} & \multirow{2}{*}{$\begin{array}{l}26-27^{\circ} \mathrm{C} \\
\mathrm{pH} 5.5-6.5\end{array}$} \\
\hline & & & $\mathrm{pH} 8$ & $\mathrm{pH} 5.5-6.5$ & $\mathrm{pH} 8$ & $\mathrm{pH} 5.5-6.5$ & & $\mathrm{pH} 8$ & pH 5.5-6.5 & \\
\hline $\mathrm{B}$ & $\mathrm{mg} / \mathrm{kg}$ & 172.14 & 233.92 & 134.22 & 176.98 & 280.00 & 115.29 & 207.50 & 89.90 & 141.67 \\
\hline $\mathrm{Ca}$ & $\%$ & 1.80 & 1.93 & 1.81 & 2.39 & 2.50 & 1.62 & 2.68 & 1.89 & 2.23 \\
\hline $\mathrm{C}$ & $\%$ & 28.60 & 28.60 & 29.50 & 30.10 & 33.40 & 26.60 & 29.90 & 28.60 & 27.50 \\
\hline $\mathrm{Cu}$ & $\mathrm{mg} / \mathrm{kg}$ & 135.00 & 13.96 & 19.32 & 13.72 & 38.31 & 50.55 & 20.86 & 21.88 & 17.59 \\
\hline $\mathrm{Fe}$ & $\mathrm{mg} / \mathrm{kg}$ & 80.00 & 211.18 & 460.59 & 153.65 & 717.50 & 80.31 & 178.75 & 635.29 & 494.89 \\
\hline $\mathrm{Mg}$ & $\%$ & 1.30 & 1.31 & 1.53 & 1.20 & 1.54 & 0.68 & 1.34 & 1.22 & 1.50 \\
\hline $\mathrm{Mn}$ & $\mathrm{mg} / \mathrm{kg}$ & 11.54 & 20.68 & 9.09 & 28.03 & 6.29 & 7.95 & 15.24 & 10.55 & 6.26 \\
\hline $\mathrm{P}$ & $\%$ & 0.18 & 0.14 & 0.11 & 0.13 & 0.10 & 0.14 & 0.15 & 0.11 & 0.08 \\
\hline $\mathrm{K}$ & $\%$ & 9.05 & 7.38 & 3.93 & 5.08 & 1.07 & 12.17 & 6.47 & 8.05 & 2.31 \\
\hline $\mathrm{Na}$ & $\%$ & 1.84 & 2.45 & 7.15 & 2.51 & 3.44 & 2.39 & 2.85 & 3.70 & 6.69 \\
\hline S & $\%$ & 1.67 & 1.66 & 1.77 & 1.35 & 1.87 & 1.12 & 1.49 & 1.61 & 1.40 \\
\hline Total N & $\%$ & 1.43 & 1.48 & 1.67 & 1.73 & 1.86 & 1.31 & 1.77 & 1.59 & 1.25 \\
\hline $\mathrm{Zn}$ & $\mathrm{mg} / \mathrm{kg}$ & 65.00 & 468.90 & 392.21 & 444.83 & 510.00 & 29.08 & 755.13 & 497.72 & 370.88 \\
\hline $\mathrm{C}: \mathrm{N}: \mathrm{P}$ & & $159: 8: 1$ & $204: 11: 1$ & $268: 15: 1$ & $232: 13: 1$ & $334: 19: 1$ & $190: 9: 1$ & $199: 12: 1$ & $260: 14: 1$ & $344: 16: 1$ \\
\hline
\end{tabular}

Note: The total mortality of $S$. podacanthum in cultured in $\mathrm{K}^{+}$-fortified inland saline water at $26-27^{\circ} \mathrm{C}$, water $\mathrm{pH}$ of 8 at day 28 providing no samples for analysis

The chemical composition of the Sargassum is presented in Table 3, of which, after one month of cultivation, the $\mathrm{N}$ content increased, the $\mathrm{P}$ reduced and $\mathrm{C}$ either remained unchanged or increased. Overall, the $\mathrm{C}: \mathrm{N}: \mathrm{P}$ ratios were higher than at the commencement of the trial. The $\mathrm{Cu}$ contents in both Sargassum spp. reduced significantly after a month in cultivation, however the $\mathrm{Zn}$ was accumulated from the water which resulted in higher $\mathrm{Zn}$ concentration in seaweed at day 28 than the commencement of the trial.

\section{Water Quality Parameters}

The water quality parameters, including $\mathrm{NO}_{3}{ }^{-}-\mathrm{N}$, $\mathrm{NO}_{2}{ }^{-}-\mathrm{N}, \mathrm{NH}_{4}-\mathrm{N}, \quad \mathrm{TKN}$ and $\mathrm{PO}_{4}{ }^{3-}-\mathrm{N}$ showed no correlation with SGR of the Sargassum. The $\left[\mathrm{NO}_{3}^{-}{ }^{-} \mathrm{N}\right]$ at the lower $\mathrm{pH}$ was about 10-20 times higher than the ambient $\mathrm{pH}$. The $\left[\mathrm{NO}_{2}{ }^{-}-\mathrm{N}\right]$ increased significantly $(p<0.05)$ as the experiment progressed and the higher temperature resulted in higher nitrite (Table 4).

The $\mathrm{NH}_{4}-\mathrm{N}$ was negligible in the first month and close to $0.1 \mathrm{mg} \mathrm{L}^{-1}$ at the completion of the trial. The 
TKN significantly $(\mathrm{p}<0.05)$ decreased at the lower $\mathrm{pH}$. The $\mathrm{PO}_{4}{ }^{3-}-\mathrm{P}$ remained unchanged as the time progressed and presented no significant differences in various $\mathrm{pH}$ and temperatures; the exception being that in $S$. linearifolium where it was higher in low $\mathrm{pH}$ than ambient $\mathrm{pH}$ at the same temperature.

The lower $\mathrm{pH}$ significantly $(\mathrm{p}<0.05)$ resulted in higher $\mathrm{NO}_{3}^{-}-\mathrm{N}, \quad \mathrm{NO}_{2}^{-}-\mathrm{N}, \quad \mathrm{TKN}$ and $\mathrm{PO}_{4}{ }^{3-}-\mathrm{P}$ concentrations in water than ambient $\mathrm{pH}$ due to the $\mathrm{HNO}_{3}$ provided. However, no water quality parameter shown a significant effects on the SGR of the seaweeds (Table 5). The one-way ANCOVA results reproved the no significant $(\mathrm{p}>0.05)$ effect of $\mathrm{NO}_{3}^{-}-\mathrm{N}$ or $\mathrm{NO}_{2}^{-}-\mathrm{N}$ on the SGR of the seaweeds between two $\mathrm{pH}$ groups, neither nor among eight treatments (Table 6). The temperature presented no effect on these water quality parameters.
The ionic composition of water is provided in Table 7, of which, after a month of cultivating Sargassum, the sodium ions were different from the commencement, while the $\left[\mathrm{K}^{+}\right]$remained unchanged over the cultured period and the heavy metals remained less than $0.05 \mathrm{mg} \mathrm{L}^{-1}$ except for $\mathrm{Zn}$ in water cultured $S$. linearifolium under low $\mathrm{pH}$ and low temperature and in water culture $S$. podacanthum under low $\mathrm{pH}$ and high temperature.

At high temperatures, the DO gradually increased from early afternoon to noon of the next day; whereas, at low temperature, the DO reduced by night and rose in the morning. During a day, the $\mathrm{pH}$ was normally increased in the morning, reached a peak at noon and decreased in the afternoon, lowest by 5.30 PM.

Table 4: Quality parameters $\left(\mathrm{mg} \mathrm{L}^{-1}\right)$ of the $\mathrm{K}^{+}$-fortified inland saline water cultured Sargassum spp. at two levels of pH and two levels of temperature as the experiment progressed

\begin{tabular}{|c|c|c|c|c|c|c|c|c|}
\hline \multirow[b]{3}{*}{ Para-meters } & \multicolumn{4}{|c|}{ S. lineariforlium } & \multicolumn{4}{|l|}{ S. podacanthum } \\
\hline & \multicolumn{2}{|l|}{$21-22^{\circ} \mathrm{C}$} & \multicolumn{2}{|l|}{$26-27^{\circ} \mathrm{C}$} & \multicolumn{2}{|l|}{$21-22^{\circ} \mathrm{C}$} & \multicolumn{2}{|l|}{$26-27^{\circ} \mathrm{C}$} \\
\hline & $\mathrm{pH} 8$ & pH 5.5-6.5 & $\mathrm{pH} 8$ & pH 5.5-6.5 & $\mathrm{pH} 8$ & pH 5.5-6.5 & $\mathrm{pH} 8$ & pH 5.5-6.5 \\
\hline \multicolumn{9}{|l|}{$\mathrm{NO}_{2}{ }^{-}-\mathrm{N}$} \\
\hline Day 1 & ${ }_{1} 0.020 \pm 0.002^{\mathrm{b}}$ & ${ }_{1} 0.150 \pm 0.021^{\mathrm{a}}$ & ${ }_{1} 0.020 \pm 0.002^{\mathrm{b}}$ & ${ }_{12} 0.150 \pm 0.021^{\mathrm{a}}$ & ${ }_{1} 0.020 \pm 0.002^{\mathrm{b}}$ & ${ }_{1} 0.150 \pm 0.021^{\mathrm{a}}$ & ${ }_{1} 0.020 \pm 0.002^{\mathrm{b}}$ & ${ }_{1} 0.150 \pm 0.021^{\mathrm{a}}$ \\
\hline Day 14 & ${ }_{2} 0.005 \pm 0.002^{\mathrm{b}}$ & ${ }_{1} 0.018 \pm 0.005^{\mathrm{ab}}$ & ${ }_{1} 0.026 \pm 0.007^{\mathrm{ab}}$ & ${ }_{1} 0.055 \pm 0.015^{\mathrm{a}}$ & ${ }_{1} 0.016 \pm 0.003^{b}$ & ${ }_{1} 0.013 \pm 0.004^{\mathrm{b}}$ & ${ }_{2} 0.081 \pm 0.026^{\mathrm{a}}$ & ${ }_{1} 0.115 \pm 0.025^{\mathrm{a}}$ \\
\hline Day 28 & ${ }_{2} 0.002 \pm 0.000^{\mathrm{c}}$ & ${ }_{1} 0.317 \pm 0.030^{\mathrm{a}}$ & ${ }_{2} 0.102 \pm 0.033^{\mathrm{bc}}$ & ${ }_{2} 0.166 \pm 0.073^{\mathrm{b}}$ & ${ }_{1}^{0.015 \pm 0.003^{c}}$ & ${ }_{1} 0.184 \pm 0.098^{b}$ & ${ }_{3} 0.375 \pm 0.000^{\mathrm{a}}$ & ${ }_{2} 0.375 \pm 0.000^{\mathrm{a}}$ \\
\hline Day 42 & ${ }_{3} 0.013 \pm 0.003^{\mathrm{b}}$ & ${ }_{2} 5.333 \pm 0.667^{\mathrm{a}}$ & & & ${ }_{2} 0.008 \pm 0.002^{b}$ & ${ }_{2} 5.333 \pm 0.667^{\mathrm{a}}$ & & \\
\hline \multicolumn{9}{|l|}{$\mathrm{NO}_{3}{ }^{-}-\mathrm{N}$} \\
\hline Day 1 & ${ }_{1} 2.53 \pm 0.12^{\mathrm{b}}$ & $27.67 \pm 0.44^{\mathrm{a}}$ & ${ }_{1} 2.53 \pm 0.12^{\mathrm{b}}$ & $27.67 \pm 0.44^{\mathrm{a}}$ & ${ }_{1} 2.53 \pm 0.12^{\mathrm{b}}$ & $127.67 \pm 0.44^{\mathrm{a}}$ & ${ }_{1} 2.53 \pm 0.12^{\mathrm{b}}$ & $27.67 \pm 0.44^{\mathrm{a}}$ \\
\hline Day 14 & ${ }_{2} 1.03 \pm 0.24^{\mathrm{b}}$ & $27.87 \pm 0.37^{\mathrm{a}}$ & ${ }_{2} 1.07 \pm 0.09^{\mathrm{b}}$ & $33.13 \pm 0.95^{\mathrm{a}}$ & ${ }_{2} 1.43 \pm 0.12^{\mathrm{b}}$ & ${ }_{1} 225.37 \pm 1.23^{\mathrm{a}}$ & ${ }_{1} 2.40 \pm 0.38^{\mathrm{b}}$ & $19.47 \pm 8.00^{\mathrm{a}}$ \\
\hline Day 28 & ${ }_{3} 0.27 \pm 0.18^{\mathrm{c}}$ & $28.53 \pm 2.47^{\mathrm{a}}$ & ${ }_{1}^{2.40 \pm 0.15^{\mathrm{b}}}$ & $25.17 \pm 1.13^{\mathrm{a}}$ & ${ }_{2} 1.07 \pm 0.12^{\mathrm{c}}$ & ${ }_{2} 23.47 \pm 1.05^{\mathrm{a}}$ & ${ }_{2} 3.47 \pm 0.55^{\mathrm{b}}$ & $25.67 \pm 0.35^{\mathrm{a}}$ \\
\hline Day 42 & $12.30 \pm 0.25^{\mathrm{b}}$ & $25.40 \pm 0.42^{\mathrm{a}}$ & & & ${ }_{1} 2.53 \pm 0.18^{\mathrm{b}}$ & ${ }_{2} 22.27 \pm 1.22^{\mathrm{a}}$ & & \\
\hline \multicolumn{9}{|l|}{$\mathrm{NH}_{4}-\mathrm{N}$} \\
\hline Day 1 & ${ }_{1} 0.01 \pm 0.00$ & $0.00 \pm 0.00$ & $0.01 \pm 0.00$ & $0.00 \pm 0.00$ & $0.01 \pm 0.00$ & ${ }_{1} 0.00 \pm 0.00$ & ${ }_{1} 0.01 \pm 0.00$ & ${ }_{1} 0.00 \pm 0.00$ \\
\hline Day 14 & ${ }_{1} 0.00 \pm 0.00$ & $0.00 \pm 0.00$ & $0.00 \pm 0.00$ & $0.00 \pm 0.00$ & $0.00 \pm 0.00$ & ${ }_{1} 0.00 \pm 0.00$ & ${ }_{1} 0.01 \pm 0.01$ & ${ }_{1} 20.02 \pm 0.02$ \\
\hline Day 28 & ${ }_{2} 0.04 \pm 0.03$ & $0.00 \pm 0.00$ & $0.02 \pm 0.02$ & $0.01 \pm 0.01$ & $0.00 \pm 0.00^{\mathrm{b}}$ & ${ }_{2} 0.11 \pm 0.03^{\mathrm{a}}$ & ${ }_{2} 0.08 \pm 0.00^{\mathrm{ac}}$ & ${ }_{2} 0.04 \pm 0.02^{\mathrm{bc}}$ \\
\hline Day 42 & ${ }_{12} 0.01 \pm 0.01^{\mathrm{a}}$ & $0.00 \pm 0.00^{\mathrm{b}}$ & & & $0.00 \pm 0.00^{\mathrm{b}}$ & ${ }_{3} 0.05 \pm 0.03^{\mathrm{a}}$ & & \\
\hline \multicolumn{9}{|l|}{ TKN } \\
\hline Day 1 & $1.14 \pm 0.16^{\mathrm{b}}$ & ${ }_{1} 10.48 \pm 0.06^{\mathrm{a}}$ & ${ }_{1} 1.14 \pm 0.16^{\mathrm{b}}$ & ${ }_{1} 10.48 \pm 0.06^{\mathrm{a}}$ & $1.14 \pm 0.16^{\mathrm{b}}$ & ${ }_{1} 10.48 \pm 0.06^{\mathrm{a}}$ & ${ }_{1} 1.14 \pm 0.16 \mathrm{~b}$ & ${ }_{1} 10.48 \pm 0.06^{\mathrm{a}}$ \\
\hline Day 14 & $1.40 \pm 0.41^{\mathrm{b}}$ & $19.85 \pm 0.12^{\mathrm{a}}$ & ${ }_{12} 1.42 \pm 0.21^{\mathrm{b}}$ & ${ }_{1} 8.68 \pm 1.28^{\mathrm{a}}$ & $1.66 \pm 0.17^{b}$ & $19.97 \pm 0.71_{\mathrm{a}}$ & ${ }_{12} 1.73 \pm 0.18 b$ & ${ }_{1} 9.34 \pm 1.03^{\mathrm{a}}$ \\
\hline Day 28 & $1.61 \pm 0.35^{\mathrm{b}}$ & ${ }_{2}^{2} .17 \pm 0.11^{\mathrm{ab}}$ & ${ }_{2} 1.77 \pm 0.20^{\mathrm{b}}$ & ${ }_{2} 3.67 \pm 1.22^{\mathrm{a}}$ & $1.56 \pm 0.45$ & ${ }_{2} 1.70 \pm 0.17$ & ${ }_{2}^{2} .45$ & ${ }_{2} 2.10 \pm 0.18$ \\
\hline Day 42 & $1.77 \pm 0.19$ & $22.19 \pm 0.06$ & & & $1.91 \pm 0.05$ & ${ }_{2} 1.77 \pm 0.25$ & & \\
\hline \multicolumn{9}{|l|}{$\mathrm{PO}_{4}^{3-}-\mathrm{P}$} \\
\hline Day 1 & $10.93 \pm 0.09$ & ${ }_{1} 1.13 \pm 0.03$ & $0.93 \pm 0.09$ & $1.13 \pm 0.03$ & ${ }_{1} 0.93 \pm 0.09$ & $1.13 \pm 0.03$ & $10.93 \pm 0.09$ & $1.13 \pm 0.03$ \\
\hline Day 14 & ${ }_{2} 0.30 \pm 0.06^{\mathrm{b}}$ & ${ }_{1} 0.67 \pm 0.12^{b}$ & $0.60 \pm 0.26^{\mathrm{ab}}$ & $3.17 \pm 2.45^{\mathrm{a}}$ & ${ }_{2} 0.37 \pm 0.03$ & $0.83 \pm 0.30$ & ${ }_{2} 1.57 \pm 0.29$ & $0.87 \pm 0.18$ \\
\hline Day 28 & ${ }_{1} 1.00 \pm 0.06^{\mathrm{bc}}$ & ${ }_{2} 2.50 \pm 0.52^{\mathrm{a}}$ & $0.93 \pm 0.20^{\mathrm{c}}$ & $1.60 \pm 0.29^{b}$ & ${ }_{3} 1.30 \pm 0.06$ & $1.00 \pm 0.00$ & ${ }_{12} 1.13 \pm 0.07$ & $1.57 \pm 0.03$ \\
\hline Day 42 & ${ }_{1} 0.93 \pm 0.19$ & ${ }_{1} 0.73 \pm 0.03$ & & & $10.83 \pm 0.07$ & $1.00 \pm 0.06$ & & \\
\hline
\end{tabular}

Values (mean \pm SE) within a row in one species sharing a common superscript are not significantly different (LSD test; $\mathrm{p}>0.05 ; \mathrm{n}=3$ ). Values (mean \pm SE) within a column sharing a common subscript are not significantly different (LSD test or t-test; $\mathrm{p}>0.05 ; \mathrm{n}=3$ ). (Data was transformed to log ( $x+10$ ) before conducting ANOVA test)

Table 5: Pearson correlation of SGR $\left(\% \mathrm{~d}^{-1}\right)$ of the Sargassum spp. cultured in $\mathrm{K}^{+}$-fortified inland saline water at two levels of $\mathrm{pH}$ and two levels of temperature and water quality parameters

\begin{tabular}{|c|c|c|c|c|c|}
\hline Criteria & $\mathrm{NO}_{2}^{-}-\mathrm{N}$ & $\mathrm{NO}_{3}{ }^{-}-\mathrm{N}$ & $\mathrm{PO}_{4}^{-3}-\mathrm{P}$ & $\mathrm{NH}_{4}-\mathrm{N}$ & TKN \\
\hline Pearson correlation & -0.120 & 0.145 & -0.027 & -0.052 & 0.235 \\
\hline Significant (2-tailed) & 0.387 & 0.296 & 0.847 & 0.710 & 0.085 \\
\hline $\mathrm{N}$ & 54.000 & 54.000 & 54.000 & 53.000 & 55.000 \\
\hline
\end{tabular}

Table 6: The effect of nitrogen on the SGR of the Sargassum spp. cultured in $\mathrm{K}^{+}$-fortified inland saline water between the two $\mathrm{pH}$ levels and among the eight treatments

\begin{tabular}{|c|c|c|c|c|c|c|c|}
\hline Group & Source & Type III sum of squares & df & Mean square & $\mathrm{F}$ & Significant & Partial eta squared \\
\hline \multirow[t]{2}{*}{ Two pH levels } & $\mathrm{NO}_{3}{ }^{-}-\mathrm{N}$ & 0.00008 & 1 & 0.00008 & 0.050 & 0.825 & 0.001 \\
\hline & $\mathrm{NO}_{2}^{-}-\mathrm{N}$ & 0.00300 & 1 & 0.00300 & 1.746 & 0.192 & 0.033 \\
\hline \multirow[t]{2}{*}{ Eight treatments } & $\mathrm{NO}_{3}^{-}-\mathrm{N}$ & 0.00100 & 1 & 0.00100 & 0.293 & 0.591 & 0.006 \\
\hline & $\mathrm{NO}_{2}^{-}-\mathrm{N}$ & 0.00500 & 1 & 0.00500 & 3.676 & 0.062 & 0.076 \\
\hline
\end{tabular}


Table 7: Ionic profile $\left(\mathrm{mg} \mathrm{L}^{-1}\right)$ of the $\mathrm{K}^{+}$-fortified inland saline water cultured Sargassum spp. at two levels of pH and two levels of temperature by day 1 and day 28 of the experiment

\begin{tabular}{|c|c|c|c|c|c|c|c|c|c|}
\hline \multirow[b]{4}{*}{ Parameters } & \multirow[b]{4}{*}{ Day 1} & \multicolumn{8}{|l|}{ Day 28} \\
\hline & & \multicolumn{4}{|c|}{ S. lineariforlium } & \multicolumn{4}{|c|}{ S. podacanthum } \\
\hline & & \multicolumn{2}{|c|}{$21-22^{\circ} \mathrm{C}$} & \multicolumn{2}{|c|}{$26-27^{\circ} \mathrm{C}$} & \multicolumn{2}{|c|}{$21-22^{\circ} \mathrm{C}$} & \multicolumn{2}{|c|}{$26-27^{\circ} \mathrm{C}$} \\
\hline & & $\mathrm{pH} 8$ & pH 5.5-6.5 & pH 8 & pH 5.5-6.5 & pH 8 & pH 5.5-6.5 & pH 8 & $\mathrm{pH} 5.5-6.5$ \\
\hline $\mathrm{B}$ & 0.66 & 0.76 & 0.72 & 0.86 & 0.86 & 0.77 & 0.67 & 0.81 & 0.84 \\
\hline $\mathrm{Ca}$ & 583.00 & 554.00 & 520.00 & 576.00 & 606.00 & 570.00 & 474.00 & 536.00 & 618.00 \\
\hline $\mathrm{Cu}$ & $<0.05$ & $<0.05$ & $<0.05$ & $<0.05$ & $<0.05$ & $<0.05$ & $<0.05$ & $<0.05$ & $<0.05$ \\
\hline $\mathrm{Fe}$ & $<0.05$ & $<0.05$ & $<0.05$ & $<0.05$ & $<0.05$ & $<0.05$ & $<0.05$ & $<0.05$ & $<0.05$ \\
\hline $\mathrm{Mg}$ & 1525.00 & 1384.00 & 1304.00 & 1526.00 & 1540.00 & 1492.00 & 1229.00 & 1464.00 & 1680.00 \\
\hline $\mathrm{Mn}$ & $<0.05$ & $<0.05$ & $<0.05$ & $<0.05$ & $<0.05$ & $<0.05$ & $<0.05$ & $<0.05$ & $<0.05$ \\
\hline $\mathrm{P}$ & 0.07 & $<0.05$ & $<0.05$ & 0.09 & 0.11 & $<0.05$ & $<0.05$ & $<0.05$ & 0.05 \\
\hline $\mathrm{K}$ & 351.50 & 351.00 & 361.00 & 369.00 & 366.00 & 359.00 & 347.00 & 364.00 & 359.00 \\
\hline $\mathrm{Na}$ & 8719.00 & 7886.00 & 7282.00 & 8591.00 & 8838.00 & 7251.00 & 7141.00 & 8308.00 & 9452.00 \\
\hline $\mathrm{S}$ & 602.4 .0 & 763.00 & 716.00 & 824.00 & 818.00 & 765.00 & 791.00 & 780.00 & 816.00 \\
\hline $\mathrm{Zn}$ & $<0.05$ & $<0.05$ & 0.12 & $<0.05$ & $<0.05$ & $<0.05$ & $<0.05$ & $<0.05$ & 0.24 \\
\hline
\end{tabular}

\section{Discussion}

Temperature and $\mathrm{pH}$ strongly influence the growth of Sargassum (Choi et al., 2007; Chen and Zou, 2014; Hwang et al., 2015). The Sargassum growth rate is strongly affected by the variation of temperature (Uchida, 1993; Endo et al., 2013) and the effect of temperature within the tested range was stronger than the $\mathrm{pH}$, shown by the significant different SGR of Sargassum at different temperature levels. The temperature affects many aspects of the growth of seaweeds, such as the photosynthetic activity (Ding et al., 2013) and respiration rate (Davison et al., 1991), ammonium and nitrogen uptake rate (Duke et al., 1989; Hwang et al., 2004). The range of studied temperature was within a preferred range of $20-30^{\circ} \mathrm{C}$ for S. patens, resulting in higher SGR (Endo et al., 2013). In the open sea, the $S$. linearifolium maximum biomass increases in May, when temperature is about $22-24^{\circ} \mathrm{C}$ and reaches maximum wet weight and length in August to November when the temperature ranges from $24-28^{\circ} \mathrm{C}$ and ceases in summer when temperature reaches over $29^{\circ} \mathrm{C}$ (Martin-Smith, 1993). The temperature window in this experiment at $20-22^{\circ} \mathrm{C}$, given the higher growth rate of Sargassum than the higher temperature of $26-27^{\circ} \mathrm{C}$, is similar to the natural maximal growth rate condition. Both Sargassum species could not be sustained after a month at a high temperature of $26-27^{\circ} \mathrm{C}$ in $\mathrm{K}^{+} \mathrm{ISW}$. Similarly, the growth of young seedlings $S$. henslowianum reduced when temperature increased to $30^{\circ} \mathrm{C}$ (Chen and Zou, 2014). The SGR of the Sargassum in this trial, were at adult stages, at $20-22^{\circ} \mathrm{C}$ is higher than the adult stage of $S$. muticum (Yamauchi, 1984) but is much lower than the juvenile $S$. horneri (Choi et al., 2007) and juvenile S. muticum (Hales and Fletcher, 1989) at $15^{\circ} \mathrm{C}$, presented the lower SGR of adults thalli and juvenile, which is similar to $S$. horneri (Lee et al., 2009). This implies a limitation of this study to lower temperatures, where more than $60 \%$ of WA inland saline ground water has the temperature lower than $20^{\circ} \mathrm{C}$ (Taukulis and John, 2009).

The lack of changes in the dried weight, ash and protein of the $S$. linearifolium as the trial progressed in the ambient temperature associating with the higher SGR than at higher temperature indicates the ambient room temperature $20-22^{\circ} \mathrm{C}$ was preferred for the growth of $S$. linearifolium than a higher temperature. The dried weight and crude protein of Sargassum in this trial is similar with Sargassum spp. from Casas-Valdez et al. (2006) (89 and $8 \%$, respectively), but protein was lower than $S$. naozhouense (11.2\%) (Peng et al., 2013). Although the $\mathrm{pH}$ and temperature did not affect the protein of the $S$. linearifolium, the effect on protein is similar to Porphyra (Kim et al., 2007), the $S$. podacanthum reduced protein shown a negatively affect by the high temperature and low $\mathrm{pH}$. The protein level of the Sargassum increased significantly as the trial progressed. This indicates the protein of Sargassum under the laboratory conditions was better than in the wild, although no independent supplementary nutrients were provided.

Seaweed culture in ISW is expecting to be a potential means in the attempt to reduce the adverse effect of ISW in the agricultural farms (Borowitzka, 1997). The $\mathrm{K}^{+}$ deficiency is in common in Australia and USA (Ingram et al., 2002; Boyd and Thunjai, 2003) although the ionic profile of ISW can be similar to OW at the same salinity (Fielder et al., 2001). Therefore, ISW should be fortified with $\mathrm{K}^{+}$at similar or about $33-66 \%$ of the $\mathrm{K}^{+}$concentration in $\mathrm{OW}$ at the same salinity for proper growth of $S$. linearifolium and Lomentaria sp., respectively (Bui et al., 2017a; 2017b). The $\mathrm{K}^{+}$plays a major role in the growth of algae and cannot be substituted by any other ion (Yarish et al., 1980). The $\mathrm{K}^{+}$ is important in the photosynthesis of the marine diatom 
(Overnell, 1975) and higher plants through the mechanism of enzyme activation in protein synthesis (Checchetto et al., 2013). The low range of $\mathrm{pH}$ changes (within 0.5) do not affect the $\mathrm{K}^{+}$movement within cells (Tromballa, 1978); however, the two different $\mathrm{pH}$ levels at 8.0 and 6.0 may cause the differential movement of $\mathrm{K}^{+}$, which in turn could affect the growth of Sargassum. As the $\mathrm{K}^{+}$movement at $\mathrm{pH} 10.0$ is slower than at $\mathrm{pH} 6.5$ (Tromballa, 1978), it is expected that in this trial, at the pH 6.0, the $\mathrm{K}^{+}$movement from the medium to the cell was faster than in the ambient $\mathrm{pH}$ of 8.0. This movement supports the photosynthesis of the Sargassum. In addition, the $\mathrm{pH}$ affects seaweed photosynthesis through the appearance of $\mathrm{CO}_{2}$ or $\mathrm{HCO}_{3}$. At low $\mathrm{pH}$ where a higher concentration of $\mathrm{CO}_{2}$ is available, the affinity for inorganic carbon is greater than at high $\mathrm{pH}$ (Aizawa and Miyachi, 1986; Drechsler and Beer, 1991), which is proved by Ulva rigida thalli photosynthesis rate (Björk et al., 1992). Thus, providing a higher biomass of Sargassum at low $\mathrm{pH}$ than the ambient $\mathrm{pH}$ in a short-term. Under the $\mathrm{pH}$ and temperature effect, the biomass of the Sagassum has varied significantly as time progressed.

The SGR of $S$. linearifolium in the ambient $\mathrm{pH}$ and ambient temperature of this study was much lower than S. linearifolium (Bui et al., 2017b), although the environmental conditions and growing season (during different years) were similar showing the different growth feasibility of whole thalli (this study) and small piece (Bui et al., 2017b).

This study reveals that the suitable $\mathrm{pH}$ for long-term growth of Sargassum in ISW was the ambient $\mathrm{pH}$ of 7.0-8.0. This $\mathrm{pH}$ range is similar to the red seaweed Gracilaria tikvahiae, G. secundata and G. manilaensis needs for high production and maximum growth rate (Skirrow, 1975; Lignell and Pedesén, 1989; Hidayat et al., 2015). Their maximal growth rate is $1.3 \% \mathrm{~d}^{-1}$ (Hidayat et al., 2015), lower than $S$. linearifolium but higher than $S$. podacanthum at the ambient $\mathrm{pH}$ in this trial. The $S$. linearifolium biomass did not significantly respond to the $\mathrm{pH}$ variation in the first month, but $S$. podacanthum biomass reduction rate was significantly slower in low $\mathrm{pH}$ than in ambient $\mathrm{pH}$. The $S$. linearifolium showed a higher SGR than $S$. podacanthum at both $\mathrm{pH}$ levels, suggesting $S$. linearifolium is a potential $\mathrm{pH}$ adaptation species in a culture where the $\mathrm{pH}$ variation is wide. The $\mathrm{pH}$ also affects the ionic absorption by seaweed (Basha and Murthy, 2007) which peaks at pH 4.5 (Figueira et al., 1997; Davis et al., 2000). The Sargassum accumulated Fe and $\mathrm{Zn}$, particularly at low $\mathrm{pH}$, but released the $\mathrm{Cu}$ to the environment when $\mathrm{Cu}$ in water is lower than 0.05 $\mathrm{mg} \mathrm{L}^{-1}$, which is a possible explanation for lower $\mathrm{Cu}$ concentration in the Sargassum tissues at the day 28 than the commencement. It is a role as a biosorbent of Sargassum in terms of environmental protection from the heavy metal pollution (Davis et al., 2003; Vijayaraghavan et al., 2009).

Hydrochloric acid $(\mathrm{HCl})$ was used in the preliminary experiment, however, it proved to be strong and reduced the water $\mathrm{pH}$ quickly and could not stabilize the $\mathrm{pH}$. On the other hand, acetic acid was too weak. Therefore, instead of $\mathrm{HCl}$ and acetic acid, $\mathrm{HNO}_{3}$ was used to reduce $\mathrm{pH}$ which potentially could result in higher $\mathrm{NO}_{3}^{-}-\mathrm{N}$ and $\mathrm{NO}_{2}^{-}-\mathrm{N}$ concentrations than under the ambient $\mathrm{pH}$ treatments. However using statistical analysis, addition of $\mathrm{HNO}_{3}$ had neither influenced SGR of Sargassum spp. nor it influenced the significant level $\mathrm{pH}$ and temperature on the SGR of Sargassum spp. Both the Pearson correltation and one-way ANCOVA presented no significant effect of $\mathrm{NO}_{3}^{-}-\mathrm{N}$ or $\mathrm{NO}_{2}^{-}-\mathrm{N}$ concentrations on the SGR of the Sargassum spp. Therefore using $\mathrm{HNO}_{3}$ did not affect the outcomes of the experiment. The $\left[\mathrm{NO}_{3}^{-}-\mathrm{N}\right]$ was sufficient for Sargassum under the both low and ambient $\mathrm{pH}$ treatments, as Sargassum consumes $\mathrm{NO}_{3}^{-}-\mathrm{N}$ when $\mathrm{NH}_{4}-\mathrm{N}$ is not available (Jie et al., 2008). As the N:P ratios under the low $\mathrm{pH}$ regime were much higher than the $\mathrm{N}: \mathrm{P}$ ratios in the ambient $\mathrm{pH}$, the nutrient consumption of the Sargassum was affected when the N:P ratio is high, resulting in higher biomass of the Sargassum in very short term.

The N:P ratio of the Sargassum in this study was much lower than the N:P of $S$. echinocarpum (Larned, 1998 ) and much lower than the $C: N: P$ ratio for Australian Sargassum (Atkinson and Smith, 1983). The reason is the P content of Sargassum in this study was much higher whereas the $\mathrm{C}$ and $\mathrm{N}$ contents were similar. These can be explained by the $\mathrm{N}: \mathrm{P}$ in this study was lower than 30:1, the Sargassum growth is N-limited (Harrison and Hurd, 2001) and the surplus P was stored in Sargassum tissue.

\section{Conclusion}

The Sargassum linearifolium and $S$. podacanthum grow faster in $\mathrm{K}^{+} \mathrm{ISW} 35 \mathrm{ppt}$ at $\mathrm{pH}$ 7-8.2 and temperature $20-22^{\circ} \mathrm{C}$ than in lower $\mathrm{pH}$ and higher temperature, which are suitable for the growing season of Sargassum in the early summer and the availability of ISW after the rainy season. The low $\mathrm{pH}$ negatively affects the growth of Sargassum and significantly affects the water quality and the chemical composition of Sargassum. Only $S$. linearifolium can grow in either low $\mathrm{pH}(5.5-6.5)$ or at the temperature of $26-27^{\circ} \mathrm{C}$ in $\mathrm{K}^{+} \mathrm{ISW}$ up to 28 days. A further study about the higher than the ambient $\mathrm{pH} 8$ and temperature of $15^{\circ} \mathrm{C}$ of $\mathrm{K}^{+} \mathrm{ISW}$ effects on the growth feasibility of Sargassum spp. is recommended.

\section{Acknowledgement}

We thank Dr. Thomas Kalb, Mr. Chau Do, Dr. Van Thang Nguyen, Proof-reading-service.com Ltd for proofreading this paper. 


\section{Funding Information}

This work was funded by the Vietnamese Ministry of Education and Curtin International Postgraduate Research Scholarship and conducted at Curtin University, Australia.

\section{Author's Contributions}

Ha Thi Thu Bui: Correspondent author, as a part of the $\mathrm{PhD}$ thesis, who was responsible for setting up and running the experiment, collecting and analysing data, writing the manuscript.

Trong Quoc Luu: Helped with seaweeds collection, experimental setup and data collection.

Ravi Fotedar: Supervised the research, edit and approved the manuscript.

\section{Ethics}

This article is original material. The corresponding author confirms that all authors have read and approved the manuscript. No ethical issue that may arise after the publication of this manuscript.

\section{References}

ABS, 2002. 4615.0-Salinity on Australian farms. Canberra Time: Australia Bureau of Statistics.

Aizawa, K. and S. Miyachi, 1986. Carbonic anhydrase and $\mathrm{CO}_{2}$ concentrating mechanisms in microalgae and cyanobacteria. FEMS Microb. Rev., 39: 19-19. DOI: 10.1016/0378-1097(86)90447-7

Allan, G.L., B. Banens and D.S. Fielder, 2001. Developing commercial inland saline aquaculture in Australia: Part 2. Resource inventory and assessment. FRDC Project No. 98/335, Canberra, Fisheries Research Development Corporation: Fisheries 389 Research Development Corporation.

Ara, J., S. Ehteshamul-Haque, V. Sultana, A. Ghaffar and R. Qasim, 1997. Use of Sargassum species for the control of Meloidogyne javanica in Okra. Nematologia Mediterranea, 25: 125-128.

Atkinson, M.J. and S.V. Smith, 1983. C:N:P ratios of benthic marine plants. Limnol. Oceanography, 28: 568-574. DOI: $10.2307 / 2835836$

Basha, S. and Z.V.P. Murthy, 2007. Seaweeds for Engineering Metal Biosorption: A Review. In: Focus on Hazardous Materials Research, Mason, L. G. (Ed.), Nova Science Publishers, New York, ISBN-10: 1600214525.

Bast, F., 2014. An illustrated review on cultivation and life history of agronomically important seaplants. In: Seaweed: Mineral Composition, Nutritional and Antioxidant Benefits and Agricultural Uses, Pomin, V. H. (Ed.), Nova Publishers, New York, pp: 39-70.
Björk, M., K. Haglund, Z. Ramazanov, G. Garcia-Reina and M. Pedersen, 1992. Inorganic-carbon assimilation in the green seaweed Ulva rigida C.Ag. (Chlorophyta). Planta, 406: 187-152.

DOI: $10.1007 / \mathrm{BF} 00201637$

Borowitzka, M.A., 1997. Algae. In: Inland Saline Aquaculture, Smith, B. and C. Barlow (Eds.), The Australian Centre for International Agricultural Research, ACIAR proceedings No. 83, Western Australia, pp: 35-36.

Boyd, C. and T. Thunjai, 2003. Concentrations of major ions in waters of inland shrimp farms in China, Ecuador, Thailand and the United States. J. World Aquac. Society, 34: 524-533. DOI: 10.1111/j.1749-7345.2003.tb00092.x

Boyd, C.A., C.E. Boyd and D.B. Rouse, 2007. Potassium budget for inland, saline water shrimp ponds in Alabama. Aquacul. Eng., 36: 45-50. DOI: 10.1016/j.aquaeng.2006.06.002

Bui, H.T.T., T.Q. Luu and R. Fotedar, 2017a. The growth feasibility of Lomentaria sp. in laboratory conditions. Environ. Risk Assess. Remediat., 1: 47-55.

Bui, H.T.T., T.Q. Luu, R. Fotedar and U. Tantulo, 2017b. Productivity of Sargassum linearifolium in potassium fortified inland saline water under laboratory conditions. Aquac. Res., 48: 5631-5639. DOI: 10.1111/are.13385

Casas-Valdez, M., H. Hernández-Contreras, A. MarínAlvarez, N.R. Aguila-Ramírez and C.J. HernándezGuerrero et al., 2006. The seaweed Sargassum (Sargassaceae) as tropical alternative for goats' feeding. Rev. Biol. Trop., 54: 83-92. PMID: 18457178

Checchetto, V., E. Teardo, L. Carraretto, E. Formentin and E. Bergantino et al., 2013. Regulation of photosynthesis by ion channels in cyanobacteria and higher plants. Biophys. Chem., 182: 51-57. DOI: $10.1016 /$ j.bpc.2013.06.006

Chen, B. and D. Zou, 2014. Growth and photosynthetic activity of Sargassum henslowianum (Fucales, Phaeophyta) seedlings in responses to different light intensities, temperatures and $\mathrm{CO}_{2}$ levels under laboratory conditions. Marine Biol. Res., 410: 1019-1026. DOI: 10.1080/17451000.2013.872798

Choi, H.G., K.H. Lee, H.I. Yoo, P.J. Kang and Y.S. Kim et al., 2007. Physiological differences in the growth of Sargassum horneri between the germling and adult stages. J. Applied Phycol., 20: 279-285. DOI: $10.1007 / \mathrm{s} 10811-007-9281-5$

Lee, K.H. H.I. Yoo, P.J. Kang and Y.S. Kim, 2009. Physiological differences in the growth of Sargassum horneri between the germling and adult stages. Proceedings of the 19th International Seaweed Symposium, Mar. 26-31, Springer, Dordrecht, Netherlands, Kobe, Japan. 
Davis, T.A., B. Volesky and A. Mucci, 2003. A review of the biochemistry of heavy metal biosorption by brown algae. Water Res., 37: 4311-4330. DOI: 10.1016/S0043-1354(03)00293-8

Davis, T.A., B. Volesky and R.H.S.F. Vieira, 2000. Sargassum seaweed as biosorbent for heavy metals. Water Res., 34: 4270-4278. DOI: $10.1016 / \mathrm{S} 0043-1354(00) 00177-9$

Davison, I.R., R.M. Greene and E.J. Podolak, 1991. Temperature acclimation of respiration and photosynthesis in the brown alga Laminaria saccharina. Marine Biol., 110: 449-454. DOI: $10.1007 / \mathrm{BF} 01344363$

Ding, L., Y. Ma, B. Huang and S. Chen, 2013. Effects of seawater salinity and temperature on growth and pigment contents in Hypnea cervicornis J. Agardh (Gigartinales, Rhodophyta). BioMed Res. Int., 2013: 1-10. DOI: $10.1155 / 2013 / 594308$

Dinh, H.Q., 2016. Cultural biology of the blue mussel, Mytilus edulis (Linnaeus, 1758) in inland saline water in Western Australia. PhD thesis, Curtin University.

Doroudi, M.S., D.S. Fielder, G.L. Allan and G.K. Webster, 2006. Combined effects of salinity and potassium concentration on juvenile mulloway (Argyrosomus japonicus, Temminck and Schlegel) in inland saline groundwater. Aquac. Res., 37: 1034-1039. DOI: 10.1111/j.1365-2109.2006.01525.x

Doupé, R.G., A.J. Lymbery and M.R. Starcevich, 2003. Rethinking the land: The development of inland saline aquaculture in Western Australia. Int. J. Agric. Sustainability, 1: 30-37. DOI: 10.3763/ijas.2003.0104

Drechsler, Z. and S. Beer, 1991. Utilization of inorganic carbon by Ulva lactuca. Plant Physiol., 97: 1439-1444. PMID: 16668569

Duke, C.S., W. Litaker and J. Ramus, 1989. Effect of temperature, nitrogen supply and tissue nitrogen on ammonium uptake rates of the chlorophyte seaweeds Ulva curvata and Codium decorticatum J. Phycol., 25: 113-120.

Endo, H., K. Suehiro, J. Kinoshita, X. Gao and Y. Agatsuma, 2013. Combined effects of temperature and nutrient availability on growth and phlorotannin concentration of the brown alga Sargassum patens (Fucales; Phaeophyceae). Am. J. Plant Sci., 4: 14-20. DOI: 10.4236/ajps.2013.412A2002

Fielder, D.S. and G.L. Allan, 2003. Improving fingerling production and evaluating inland saline water culture of snapper, Pagrus auratus. NSW Fisheries Final Report Series No. 43, CRC Project No. C4.2.

Fielder, D.S., W.J. Bardsley and G.L. Allan, 2001. Survival and growth of Australian snapper, Pagrus auratus, in saline groundwater from inland New South Wales, Australia. Aquaculture, 201: 73-90. DOI: $10.1016 / \mathrm{s} 0044-8486(01) 00555-5$
Figueira, M.M., B. Volesky and V.S.T. Ciminelli, 1997. Assessment of interference in biosorption of a heavy metal. Biotechnol. Bioeng., 54: 344-350.

DOI: $10.1002 /($ SICI) $1097-$ 0290(19970520)54:4<344::AID-BIT7>3.0.CO;2-K

Hales, J.M. and R.L. Fletcher, 1989. Studies on the recently introduced brown alga Sargassum muticum (Yendo) Fensholt. IV. The effect of temperature, irradiance and salinity on germling growth. Botarica Marina, 32: 167-176.

DOI: $10.1515 /$ botm.1989.32.2.167

Hanisak, M.D. and M. Samuel, 1987. Growth rates in culture of several species of Sargassum from Florida, USA. Proceedings of the 12th International Seaweed Symposium, (ISS' 87), Springer Netherlands, pp: 399-404. DOI: 10.1007/978-94-009-4057-4 59

Harrison, P.J. and C.L. Hurd, 2001. Nutrient physiology of seaweeds: Application of concepts to aquaculture. Cah. Biol. Mar., 42: 71-78.

Helrich, K.C., 1990. Official methods of Analysis. 15th Edn., Association of Official Analytical Chemists Inc. Arlington, Virginia, USA, ISBN-10: 0095584420.

Hidayat, N.S.M., N. Mohammad-Noor, D. Susanti, S. Saad and Y. Mukai, 2015. The effects of different $\mathrm{pH}$ and salinities on growth rate and carrageenan yield of Gracilaria manilaensis. J. Teknol., 77: 1-5.

Hoang, T.C., A.J. Cole, R. Fotedar, M.J. O'Leary and M.W. Lomas et al., 2016. Seasonal changes in water quality and Sargassum biomass in southwest Australia. Marine Ecol. Progress Series, 551: 63-79. DOI: $10.3354 /$ meps 11735

Huisman, J.M., 2000. Marine Plants of Australia. 1st Edn., University of Western Australia Press, Western Australia, ISBN-10: 1876268336, pp: 300.

Hur, S., H. Lee, Y. Kim, B.H. Lee and J. Shin and T.Y. Kim, 2008. Sargaquinoic acid and sargachromenol, extracts of Sargassum sagamianum, induce apoptosis in $\mathrm{HaCaT}$ cells and mice skin: Its potentiation of UVBinduced apoptosis. Eur. J. Pharmacol., 582: 1-11. DOI: 10.1016/j.ejphar.2007.12.025

Hwang, E.K., D.S. Ha, J.M. Baek, M.Y. Wee and C.S. Park, 2006. Effects of $\mathrm{pH}$ and salinity on the cultivated brown alga Sargassum fulvellum and associated animals. Algae, 21: 317-321. DOI: 10.4490 /algae.2006.21.3.317

Hwang, E.K., H.C. Yoo, J.M. Baek and C.S. Park, 2015. Effect of $\mathrm{pH}$ and salinity on the removal of phytal animals during summer cultivation of Sargassum fusiforme and Sargassum fulvellum in Korea. J. Applied Phycol., 27: 1985-1989. DOI: $10.1007 / \mathrm{s} 10811-014-0511-3$

Hwang, R.L., C.C. Tsai and T.M. Lee, 2004. Assessment of temperature and nutrient limitation on seasonal dynamics among species of Sargassum from a coral reef in Southern Taiwain. J. Phycol., 40: 463-473. DOI: $10.1111 / \mathrm{j} .1529-8817.2004 .03086 . x$ 
Ingram, B.A., L.J. Mckinnon and G.J. Gooley, 2002. Growth and survival of selected aquatic animals in two saline groundwater evaporation basins: An Australian case study. Aquaculture Res., 33: 425-436. DOI: 10.1046/j.1365-2109.2002.00691.X

Jie, B., T. Xiang-Li, D. Shuang-Lin and J. Hong-Bo, 2008. Effect of temperature,salinity and light intensity on nitrogen and phosphorus uptake by Sargassum thunbergii. J. Fishery Sci. China.

Kim, J.K., G.P. Kraemer, C.D. Neefus, I.K. Chung and C. Yarish, 2007. Effects of temperature and ammonium on growth, pigment production and nitrogen uptake by four species of Porphyra (Bangiales, Rhodophyta) native to the New England coast. J. Applied Phycol., 19: 431-440.

DOI: $10.1007 / \mathrm{s} 10811-006-9150-7$

Kolkovski, S., 2010. An overview on desert aquaculture in Australia. Proceedings of the Aquaculture in desert and arid lands: Development constraints and opportunities, Jul. 69, FAO, Hermosilli, Maxico, pp: 39-60.

Larned, S.T., 1998. Nitrogen-versus phosphorus-limited growth and sources of nutrients for coral reef macroalgae. Marine Biol., 132: 409-421.

DOI: $10.1007 / \mathrm{s} 002270050407$

Lee, C.L., 1997. Potential for Inland Aquaculture of Crustaceans. In: Inland Saline Aquaculture, Perth, Smith, B. and C. Barlow (Eds.), The Australian Centre for International Agricultural Research, ACIAR Proceedings No. 83, Perth, pp: 37-39.

Lignell, A. and M. Pedesén, 1989. Effects of $\mathrm{pH}$ and inorganic carbon concentration on growth of Gracilaria secundata. Bristish Phycol. J., 24: 83-89. DOI: 10.1080/00071618900650071

Lymbery, A.J., R.G. Doupé, T. Bennett and M.R. Starcevich, 2006. Efficacy of a subsurface-flow wetland using the estuarine sedge Juncus kraussii to treat effluent from inland saline aquaculture. Aquaculture Eng., 34: 1-7.

DOI: 10.1016/j.aquaeng.2005.03.004

Martin-Smith, K.M., 1993. The phenology of four species of Sargassum at magnetic Island, Australia. Botanica Marina, 36: 327-334.

DOI: $10.1515 /$ botm. 1993.36.4.327

Mazor, E. and R. George, 1992. Marine airborne salts applied to trace evapotranspiration, local recharge and lateral groundwater flow in Western Australia. J. Hydrol., 139: 63-77.

DOI: 10.1016/0022-1694(92)90195-2

Nulsen, B., 1997. Inland Saline Water in Australia. In: Inland Aquaculture Workshop, Smith, B. and C. Barlow (Eds.), The Australian Centre for International Agricultural Research, ACIAR Proceedings No. 83, Perth, pp: 6-11.
Nurmi, P.A., I.T. Kukkonen and P.W. Lahermo, 1988. Geochemistry and origin of saline groundwaters in the Fennoscandian Shield. Applied Geochemistry, 3: 185-203. DOI: $10.1016 / 0883-2927(88) 90007-8$

Ogawa, H., 1984. Effects of treated municipal wastewater on the early development of sargassaceous plants. Hydrobiologia, 116-117: 389-392. DOI: $10.1007 / \mathrm{BF} 00027707$

Ogburn, D.M., 1997. Environmental Considerations in the Use and Management of Inland Saline Water Bodies for Aquaculture. In: Inland Saline Aquaculture, Smith, B. and C. Barlow (Eds.), The Australian Centre for International Agricultural Research, ACIAR Proceedings No. 83, Perth, pp: 32-34.

Overnell, J., 1975. Potassium and Photosynthesis in the Marine Diatom Phaeodactylum tricornutum as Related to Washes with Sodium Chloride. Physiologia Plantarum, 35: 217-224. DOI: $10.1111 /$ j.1399-3054.1975.tb03896.x

Partridge, G.J., 2008. Inland saline aquaculture: Overcoming biological and technical constraints towards the development of an industry. PhD thesis, Murdoch.

Partridge, G.J., A.J. Lymbery and R.J. George, 2008. Finfish mariculture in inland Australia: A review of potential water sources, species and production systems. J. World Aquac. Society, 39: 291-310. DOI: $10.1111 / \mathrm{j} .1749-7345.2008 .00169 . \mathrm{x}$

Peng, Y., E. Xie, K. Zheng, M. Fredimoses and X. Yang et al., 2013. Nutritional and chemical composition and antiviral activity of cultivated seaweed Sargassum naozhouense Tseng et Lu. Mar Drugs., 11: 20-32. DOI: 10.3390/md11010020

Prangnell, D.I. and R. Fotedar, 2006a. Effect of sudden salinity change on Penaeus latisulcatus Kishinouye osmoregulation, ionoregulation and condition in inland saline water and potassiumfortified inland saline water. Comparative Biochem. Physiol. Part A: Molecular Integrative Physiol., 145: 449-457.

DOI: $10.1016 /$ j.cbpa.2006.08.029

Prangnell, D.I. and R. Fotedar, 2006b. The growth and survival of western king prawns, Penaeus latisulcatus Kishinouye, in potassium-fortified inland saline water. Aquaculture, 259: 234-242. DOI: $10.1016 /$ j.aquaculture.2006.05.023

Schaffelke, B. and D.W. Klumpp, 1998. Nutrient-limited growth of the coral reef macroalga Sargassum baccularia and experimental growth enhancement by nutrient addition in continuous flow culture. Marine Ecol. Progress Series, 164: 199-211.

DOI: $10.3354 /$ meps 164199 
Skirrow, G., 1975. The dissolved gases - carbon dioxide. In: Chemical Oceanography, Riley, J.P. and G. Skirrow (Eds.), Academic Press, London, New York.

Taukulis, F.E. and J. John, 2006. Diatoms as ecological indicators in lakes and streams of varying salinity from the wheat belt region of Western Australia. J. Royal Society Western Australia, 89: 17-25.

Taukulis, F.E. and J. John, 2009. Development of a diatom-based transfer function for lakes and streams severely impacted by secondary salinity in the south-west region of Western Australia. Hydrobiologia, 626: 129-143. DOI: $10.1007 / \mathrm{s} 10750-009-9741-9$

Timms, B.V., 2005. Salt lakes in Australia: present problems and prognosis for the future. Hydrobiologia, 552: 1-15. DOI: $10.1007 / \mathrm{s} 10750-005-1501-\mathrm{x}$

Tromballa, H.W., 1978. Influence of permeant acids and bases on net potassium uptake by Chlorella. Planta, 138: 243-248. DOI: 10.1007/BF00386818

Uchida, T., 1993. The life cylcle of Sargassum horneri (Phaeophyta) in laboratory culture. J. Phycol., 29: 231-235.

DOI: $10.1111 / \mathrm{j} .0022-3646.1993 .00231 . x$

Vijayaraghavan, K., T.T. Teo, R. Balasubramanian and U.M. Joshi, 2009. Application of Sargassum biomass to remove heavy metal ions from synthetic multi-metal solutions and urban storm water runoff. J. Hazardous Materi., 164: 1019-1023. DOI: $10.1016 /$ j.jhazmat.2008.08.105

Wang, B., H. Huang, H.P. Xiong, E.Y. Xie and Z.M. Li, 2010a. Analysis on nutrition constituents of Sargassum naozhouense sp. Food Res. Dev., 31: 195-197.
Wang, J., Q. Zhang, Z. Zhang, H. Zhang and X. Niu, 2010 b. Structural studies on a novel fucogalactan sulfate extracted from the brown seaweed Laminaria japonica. Int. J. Biol. Macromolecules, 47: 126-131. DOI: 10.1016/j.ijbiomac.2010.05.010

Wiltshire, K.H., J.E. Tanner, C.F.D. Gurgel and M.R. Deveney, 2015. Feasibility study for integrated multitrophic aquaculture in Southern Australia: Report to the Fisheries Research and Development Corporation. 1st Edn., SARDI Aquatic Sciences, Adelaide, ISBN-10: 1921563869, pp: 115.

Womersley, H.B.S., 1987. The marine benthic flora of southern Australia. 1st Edn., South Australian Government Printing Devision, Adelaide.

Yamauchi, K., 1984. The formation of Sargassum beds on artificial substrata by transplanting seedlings of $S$. horneri (Turner) C. Agardh and S. muticum (Yendo) Fensholt. Nippon Suisan Gakkaishi, 50: 1115-1123. DOI: $10.2331 /$ suisan.50.1115

Yarish, C., P. Edwards and S. Casey, 1980. The effects of salinity and calcium and potassium variations on the growth of two estuarine red algae. J. Experimental Marine Biol. Ecol., 47: 235-249. DOI: 10.1016/0022-0981(80)90041-6

Yende, S.R., U.N. Harle and B.B. Chaugule, 2014. Therapeutic potential and health benefits of Sargassum species. Pharmacognosy Rev., 8: 1-7. DOI: $10.4103 / 0973-7847.125514$ 